\title{
Effect of water supply on canopy temperature, stomatal conductance and yield quantity of processing tomato (Lycopersicon esculentum Mill.)
}

\author{
Helyes, L., Böcs.A., \& Pék, Z. \\ Department of Horticulture and Technology, Szent István University, Páter K.út 1., H-2103 Gödöllö, Hungary, \\ Helyes.Lajos@mkk.szie.hu
}

\begin{abstract}
Summary: Tomato (Lycopersicon esculentum Mill.) is one of the most extensively cultivated horticultural crops in the world. Water supply is important for yield quantity and quality. The aims of the present study were 1) to evaluate the canopy temperature and the stomatal conductance on processing tomato substances with different water supply, 2) to investigate the effect of different water supply on yield quantity.

There were two irrigated treatments, one of them was the reguralry irrigated plant stand which got 333 mm water during investigated period, including the precipitation and the other was the cut off substance which means the irrigation (drip) was stopped at the beginning of the ripening process and there was a control as well which got $189 \mathrm{~mm}$ precipitation. The canopy temperature was measured row by row with a Raytek MX 4 type infrared remote thermometer. The stomatal conductance was measured by Delta-T AP4 type porometer. There were significant differences between the control and irrigated plants according to the water supply which was formulated the canopy values. The plants with a deficient water supply were decreased the transpiration rate, therefore its cooling effect didn't show up. The regularly irrigated tomato plants' yield exceeded the unirrigated ones more than twice. It is emerged from the study that the irrigation has a positive effect on the amount of the harvestable yield in this year type.
\end{abstract}

Key words: tomato, water supply, canopy temperature, stomatal conductance

\section{Introduction}

The importance of tomato cultivation has been growing rapidly in the last decades in the world. Beside the fresh market tomatoes, the processing tomato has a great importance in the food industry. The processing tomato cultivation has changed a lot recently, the production areas were decreased, but the average yield/ha is getting higher due to the widespread use of hybrids and better growing technologies in Hungary. Processing tomato cultivation is profitable over yield of 40-50 t/ha in Hungary (Fruitveb, 2008), but it's important mention that profitability depend on lots of technological elements (mainly: propagation and irrigation methods, etc.) Ecological conditions e.g. solar radiation, temperature and water supply take a great effect on tomato yield (Helyes \& Varga, 1994; Helyes et al., 1999; Pék et al., 2008), so the irrigation is essential to keep yield higher and it is possible to increase the amount on 90-110 t/ha.

Water supply is limited worldwide and there is an increasing necessity to reduce the quantity of water used during the irrigation practices (Zegbe-Dominguez et al., 2003). Furthermore, water deficit and poor water quality are the main factors affecting yield and tomato quality in terms of nutritional value and food safety (Dorais et al., 2008). It is important to measure the different water supply on canopy by monitor the activity of stomas in the leaves. The canopy temperature can well characterise the water supply of plant stands (Cselötei \& Helyes, 1988). The prognosis could be done for the irrigation and calculation the amount of irrigation water is possible only in the view of stomatal conductance and canopy temperature (Schober et al., 2008).

\section{Materials and methods}

Tomato fruits were ensured from the test sites of Szent István University, Gödöllö. The soil is sandy forest in that area with low water capacity and the hydraulic conductivity is good. The subsoil water is below 5 meters; therefore it cannot influence the water turnover. The following variety was investigated: Brigade $\mathrm{F}_{1}$. Area of the experiment was $300 \mathrm{~m}^{2}$ and the area of one plot was $25 \mathrm{~m}^{2}$. Seeds were sown on the $7^{\text {th }}$ of April 2008 in greenhouse and transplanted on the $12^{\text {th }}$ of May 2008. Tomato seedlings were planted out in twin rows, $0.4 \mathrm{~m}$ spacing inside the raw and $1.2 \mathrm{~m}$ between adjacent twin rows, the space between the plants in the row was $0.3 \mathrm{~m}$. The treatments were the next: 1. Control, (rainfed), 2. Cut off, (irrigation cut-off 30 days before harvest) 3. Regularly irrigated. Each treatment was cultivated in four replications. Drip irrigated water was given out according to the air temperature (daily irrigation water $(\mathrm{mm})=$ average daily temperature $\times 0.2)$. The canopy temperature was measured by Raytek MX4 (Raytek Corporation, CA, USA) infrared remote thermometer and the stomatal conductance by AP4 (Delta-T Devices Ltd, UK) type porometer. These processes were taken every day within 
the crops from 1PM. Test sites were harvested by hand. All statistical analyses were performed using the Microsoft ${ }^{\circledR}$ Excel 2002 Analysis Toolpak (Microsoft Corporation Corporate Headquarters Redmond, USA). The effect of irrigation on yield significantly depends on the weather, especially on temperature and precipitation conditions during the growing season (Figure 1).

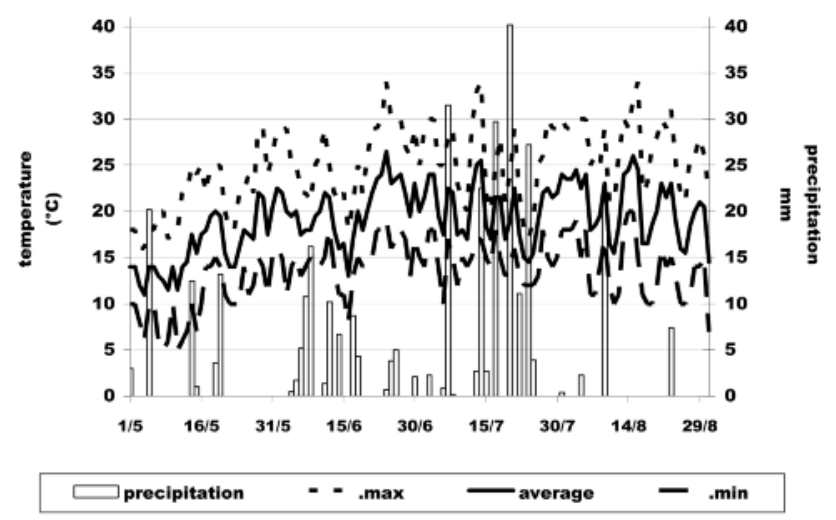

Figure 1. Daily temperature and precipitation during tomato vegetation period in 2008.

\section{Results}

According to Katerji et al. (1988), we measured the stomatal conductance first leaf above terminal cluster, which is well characterise water status of the whole plant. There is significant difference between the irrigated and unirrigated control treatment during the measuring period. Accumulated stomatal conductance was $20.2 \mathrm{~mol} \mathrm{~m}^{-2} \mathrm{~s}^{-1}$ for the regularly irrigated, $17.5 \mathrm{~mol} \mathrm{~m}^{-2} \mathrm{~s}^{-1}$ for the cut off, and only $10.2 \mathrm{~mol}$ $\mathrm{m}^{-2} \mathrm{~s}^{-1}$ for the unirrigated control plants respectively (Fig. 2). The stomas of regularly irrigated tomato plants opened up more widely, because of the high turgor capacity, therefore the water could effuse as a vapour. The unirrigated control

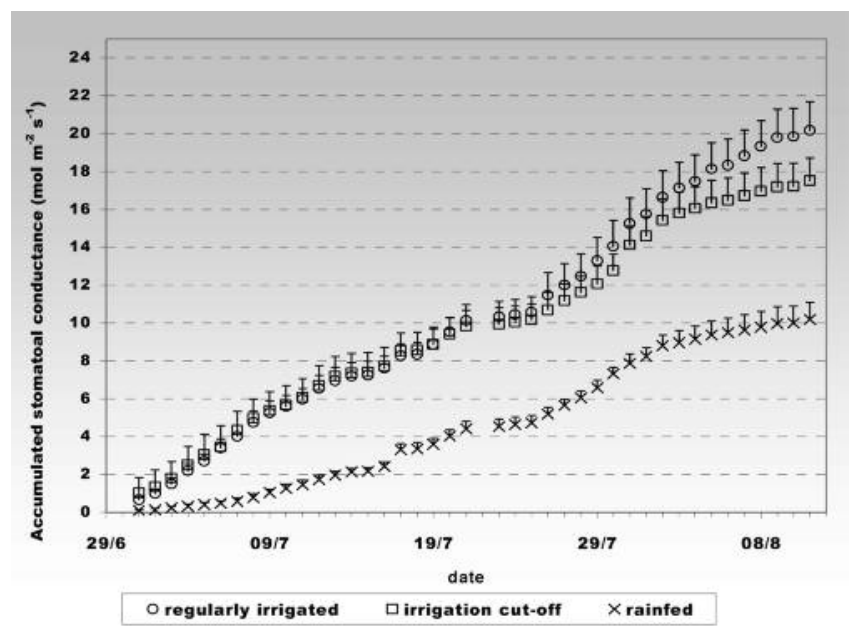

Figure 2. Accumulated stomatal conductance of processing tomato in the three different treatments during the measuring period, based on data recorded at 1PM Vertical bars represent significant differences at $\mathrm{p}=0.05(\mathrm{n}=4)$. plants showed the contrast of that, to avoid the unnecessary water loss, hence the lower conductivity value.

The canopy temperature rates confirm the difference between irrigation treatments and unirrigated control. It was appointed that there was an upward tendency in the range of control, cut off and regularly irrigated plants, the more water supplies they had the more yields they produced. The canopy temperature of control plants was $27.3{ }^{\circ} \mathrm{C}$, the irrigated plants was $26.2{ }^{\circ} \mathrm{C}$ on the average. This means $1.1{ }^{\circ} \mathrm{C}$ average deflection through a day. A deflection of $1{ }^{\circ} \mathrm{C}$ on the canopy temperature causes $10 \%$ in the transpiration rate (Tanner, 1963), therefore the regularly irrigated treatment could transpiration $10 \%$ more then the control ones. Canopy temperature of irrigated and unirrigated plant stands were split at the beginning of the treatment, and the species are separable as well.

Canopy temperatures of the plants from both treatments were under or close to the air temperature during the monitoring period, except the control treatment (Fig. 3.). Since the control's temperature was nearly always higher than the air temperature, the plants had lack of water. From the calculations it can assessed that the air temperature affects the leaves' temperature significantly. It can assess from correlation coefficients that the air temperature affects the constantly irrigated, cut-off and control plants' canopy temperature by $60-, 54-$ and $59 \%$ in range. Lower water supply coupling higher canopy temperature, which comes from the equations. In the constantly irrigated treatment the cooling effect intensify over $28^{\circ} \mathrm{C}$ air temperature.

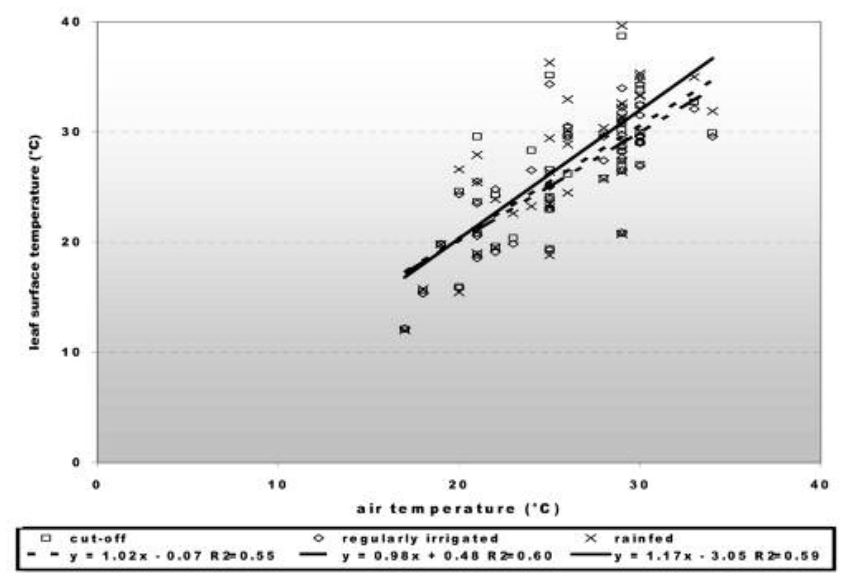

Figure 3. Correlation between canopy temperatures of different irrigated tomato treatments and air temperature, during the monitoring period at 1PM. (Brigade $\mathrm{F}_{1}, \mathrm{n}=41$ ).

In the case of water stressed plants canopy temperature is greater than air temperature. Figure 4 shows the interrelation between the canopy- and air temperature difference values and the yield quantity. In our experiments the interrelation is significant at $\mathrm{p}=0.01$ level with $\mathrm{r}^{2}=0.57$ correlation coefficient.

Low yields were harvested without irrigation, because the fruit number and size were much small. Effect of irrigation (cut off 30 day before harvest and regularly irrigated) increased the marketable (red and green) yield with $175 \%$ 


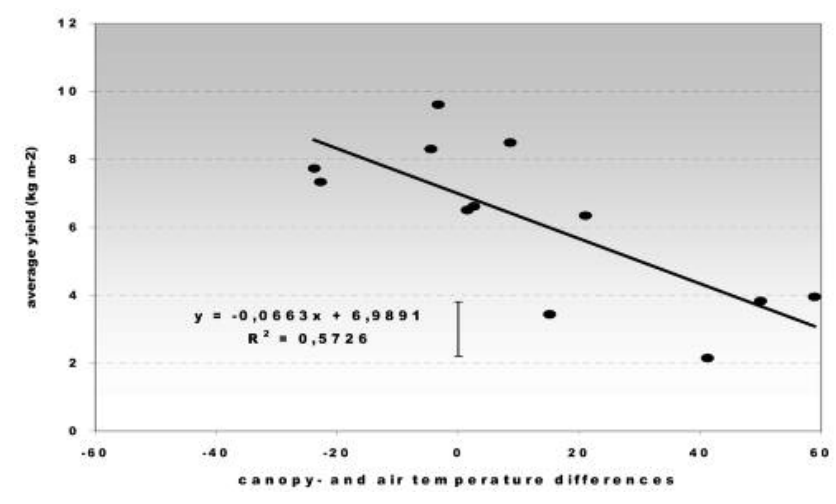

Figure 4. Correlation between canopy- air temperature differences and yield quantity

and $125 \%$ respectively. The soluble solid content of fruits was often very high without irrigation, this value decreased with irrigation. In spite of this the level of brix yield per hectar remarkably increased as a result of significantly higher yield quantity (Table 1.).

Table 1. Average yield parameters of marketable tomato fruits

\begin{tabular}{|c|c|c|c|c|c|}
\hline \multicolumn{2}{|c|}{} & $\begin{array}{c}\text { average fruit } \\
\text { weight }(\mathrm{g})\end{array}$ & $\mathbf{M p ~ h a}^{-1}$ & $\begin{array}{c}\text { marketable } \\
\text { yield }\left(\mathbf{t} \mathbf{h a}^{-\mathbf{1}}\right)\end{array}$ & $\begin{array}{c}\text { Brix yield } \\
\left(\mathbf{t ~ h a}^{-1}\right)\end{array}$ \\
\hline \multirow{2}{*}{2008} & RF & $36.8 \pm 5.6^{\mathrm{a}}$ & $3.6 \pm 0.6^{\mathrm{a}}$ & $43.8 \pm 10.6^{\mathrm{a}}$ & $2.4 \pm 0.6^{\mathrm{a}}$ \\
\cline { 2 - 6 } & CO & $53.6 \pm 2.7^{\mathrm{bc}}$ & $6.5 \pm 1.1^{\mathrm{b}}$ & $119.5 \pm 1.9^{\mathrm{c}}$ & $5.5 \pm 1.1^{\mathrm{b}}$ \\
\cline { 2 - 7 } & RI & $53.6 \pm 2.7^{\mathrm{bc}}$ & $6.7 \pm 0.3^{\mathrm{b}}$ & $98.0 \pm 9.7^{\mathrm{bc}}$ & $5.4 \pm 0.7^{\mathrm{b}}$ \\
\hline
\end{tabular}

rainfed $(\mathrm{RF})$ cut off $(\mathrm{CO})$ regularly irrigated (RI)

For each column bearing different superscript letter indicate significant differences according to Tukey's test. Values are mean \pm SD.

\section{Conclusions}

The following conclusions were drawn from this study: there were significant differences among three different water supplies in accumulated stomatal conductance, at the end of measuring period. The stomas of regularly irrigated tomato plants opened up more widely, because of the high turgor capacity, therefore the water could effuse as a vapour, while unirrigated control plants (rainfed) showed the contrast of that, to avoid the unnecessary water loss. Air temperature took strong positive effect on foliage surface (canopy) temperature. The rainfed tomato plants could not transpire sufficient water to cool leafs below air temperature and it causes stress. Regularly irrigated plants did not heat over air temperature owing to enough soil water content. Both stomatal conductance and canopy temperature is suitable to characterize the tomato plant water status.

Increasing the water supply significantly increases fruit yield but reduces significantly ${ }^{\circ}$ brix content of fruit on the other hand it is very important mention that brix yield increased also significantly.

\section{Acknowledgements}

The study was partly supported by TECH-09-A3-20090230, USOK2009 project.

\section{References}

Cselötei, L. \& Helyes, L. (1988): The possibility of determining irrigation requirements by means of plant temperature. Acta Horticulturae, 220: 353-358.

Dorais, M. Ehret, D.L. \& Papadopoulos, A.P. (2008): Tomato (Solanum lycopersicum) health components: from the seed to the consumer. Phytochem. Rev., 7: 231-250.

Fruitveb (2008): A zöldség-gyümölcs ágazat helyzete Magyarországon, 9-10.

Helyes, L. \& Varga. Gy. (1994): Irrigation demand of tomato according to the results of three decades. Acta Horticulturae, 376: 323-328.

Helyes, L. Varga, Gy. Pék, Z. \& Dimény, J. (1999): The simultaneous effect of variety, irrigation and weather on tomato yield. Acta Horticulturae, 487: 499-505.

Helyes, L. Dimény, J. Pék, Z. \& Lugasi, A. (2006): Effect of the variety and growing methods as well as cultivation conditions on ingredient of tomato (Lycopersicon lycopersicum (L.) Karsten)fruit. Acta Horticulturae, 712: 511-516.

Katerji, N. Itier, B. \& Ferreira, M. I. (1988): Etude de quelques critères indicateurs de l'état hydrique d'une culture de tomate en région semi-aride. Agronomie, 8: 425-433.

Pék, Z. Helyes, L. Dimény, J. Paksi, A. \& Böcs A. (2008): Effect of ecological conditions on tomato fruits colour and ingredients during the ripening process. Cereal Research Communications, 36 (1): 519-522.

Schober, G. Pék, Z. \& Helyes, L. (2007): Effects of drip irrigation in processing tomato (Lycopersicon lycopersicum (L.) Karsten). Cereal Research Communications, 36 (1): 627-630.

Tanner, V. (1963): Plant temperature. Agronomy Journal, 55: 210-211.

Zegbe-Domýínguez, J.A. Behboudian, M.H. Lang, A. \& Clothier, B.E. (2003): Deficit irrigation and partial root-zone drying maintain fruit dry mass and enhance fruit quality in 'Petopride' processing tomato (Lycopersicon esculentum. Mill.). Hort. Sci., 98: 505-510. 